\title{
Solid waste management: Belo Horizonte's study case
}

\author{
Evaldo de Melo Ferreira ${ }^{1}$ e Raphael Tobias de Vasconcelos Barros ${ }^{2}$ \\ ${ }^{1}$ Master of Science, Ph.D student, Environmental and Sanitary Department, Federal University of Minas Gerais, Belo Horizonte, Minas \\ Gerais, Brazil \\ emferreira.sci@gmail.com \\ ${ }^{2} \mathrm{Ph} . \mathrm{D}$, Professor in the Department of Environmental and Sanitary Department of Federal University of Minas Gerais, Belo Horizonte, \\ Minas Gerais, Brazil \\ raphael@desa.ufmg.br
}

\begin{abstract}
The main objective of this study is to present the instruments related to solid waste in Brazil, specifically in the city of Belo Horizonte, as well as to characterize the aspects of waste management abroad. In addition to websites of different governments, scientific databases were consulted, among them are: SciELO, Science Direct and Web of Science. Although having a major regulatory framework on the management of solid waste, and that the Law 12.305 of August 2010, Brazil is lagging when it comes to the application of what is regulated. In 2015, it was decided to extend the deadline for municipalities to close their dumpsters and then use landfills, which was not fulfilled. Thus, it was decided to extend the deadline, share that view by different scholars as an error. During this study, it was observed that among the major flaws in the Brazilian management model, is meeting deadlines established by law, which differs from the model adopted in Europe, after the deadline, fines are levied on the waste generator that does not comply with the provisions. Unfortunately, in Brazil, solid waste management by the government is still seen in the wrong way, for something interesting to remember is that with a good waste management, spending vector control (and therefore healthy) will be considerably reduced.
\end{abstract}

Keywords: Public policy., Environmental management, Sanitation. 


\section{INTRODUCTION}

As one of the main aspects to be considered as basic sanitation, the environmentally management of solid waste in developing countries is still seen as a difficulty to be faced. When available, environmental sanitation reduces public health costs, for example. This reduction of costs associated with sustainable development demands the adoption of environmentally adequate techniques by municipal management, particularly about solid waste management (DÍAZ-VILLAVICENCIO et al., 2017).

This is a relevant issue for municipalities, which suffer from various problems caused by the lack of management, which get worse by the continued expansion of generation and the lack of correct disposal, some of which are tangential to the complexity of solid waste management (Reuse and reuse of resources) and environmental issues (reuse, special collections and adequate final disposition) and social (generation of income and employment) (SILVA et al., 2017).

Among the regions of Brazil, the regions with the highest volumes of waste generated and with the highest volume of collected wastes are the South and Southeast regions of Brazil. Researchers point to this because of the historical process of economic formation of the national territory, which concentrated in these areas the exploitation of important factors of production, which at the time were converted into extremely urbanized areas with a high population concentration, unfolding, also in this situation (GONÇALVES et al., 2016). Although with solutions such as recycling and composting of organic matter, difficulties are faced by municipalities, where recycling is the technique of easier application in developing countries due to a lower cost of implementation compared to other options that require more Maintenance (JARA-SAMANIEGO et al., 2017).

The modifications to be implemented in Brazil regarding the management of solid urban waste and recommended in Law 12,305, of August 2, 2010, were postponed over a period of five years (established by the law). About the dumps, the capitals and municipalities of the metropolitan region will have until July 31, 2018 to end the dumps (BRAZIL, 2015). According to Jabbour et al (2014, p. 8): "as of August 2012 the municipalities should have delivered their management plans. Weeks after the deadline, $95 \%$ of the total had not delivered the documents. "

The different historical moments in which developing and developed countries are included are important to consider when evaluating the facilities and difficulties faced by society in waste management. While in industrialized countries concern for public health, scarce resources, the consequences of climate change, public awareness and participation are driving forces for waste management, in developing countries urbanization, different inequalities, growth Economic factors, social factors and institutional factors, are still a problem in the implementation of management systems (MARSHALL \& FARAHBAKHSH, 2013).

\section{THE ENVIRONMENTAL QUESTION AND INTERNATIONAL WASTE MANAGEMENT}

From the differents process of production, waste is generated. In this phase and in the final disposal, environmental aspects require greater care with their environmental management (FERREIRA et al., 2014). The environmentally waste management in the municipalities of Brazil was regulated by Federal Law n. 12,305 as of August 2, 2010. Among the options for environmentally appropriate disposal are reuse, recycling, composting, recovery and reuse (BRASIL, 2010).

Something addressed in the National Solid Waste Policy (NSWP) is that for landfills should be destined only for tailings and, still according to law 12,305, all municipalities should have this technology implanted in their areas until August 2014. The Landfills are considered the last of the waste management stages, being the least expensive and environmentally recommended technique for localities where there is availability of area and scarcity of financial resources (COUTO et al., 2013). Despite its characteristics, this technology is still little used in Brazil.

In a study carried out with 28 European countries, factors related to government, consumer and the responsibility of the entrepreneur in solid waste management were evaluated. Age, sex level of formal education, and occupation were studied at work, as well as variables such as the country of origin and the area of residence (rural or urban). 23,976 people were interviewed. Something else has been stated in other researches that women, people of higher education, who have a better job and 
who live in rural areas, or in small towns, are generally more sensitive to solid waste issues. Men and people living in a big city are more willing to entrust this responsibility to businesses. The solution to the base of government is chosen only by the people of low education. Finally, individuals with greater environmental awareness and effort prefer to pay for services, while those who are less environmentally conscious prefer government action (TRIGUERO et al., 2016).

Factors such as income of the population and level of education are determinant in the composition of solid waste. In a diagnosis made on solid waste management in cities: Adelaide (Australia), Bamako (Mali), Bengaluru (India), Cañete (Peru), Curepipe (Mauritius), Delhi (India), Dhaka (Bangladesh), Ghorahi (Nepal), Kunming (China), Lusaka (Zambia), Managua (Nicaragua), Moshi (Mexico), Nairobi (Kenya), Quezon (Philippines), Rotterdam (Netherlands), San Francisco (United States), Sousse Tompkins County (USA) and Varna (Bulgaria), different compositions of solid residues were observed.

Of the total, in 16 cities was waste generation with glass, except for Varna in Bulgaria. Eight of the studied cities have a large generation of waste with plastic, and Curepipe, Quezon City and Nairobi had a large volume of waste during the studied period. In Europe, North America and Australia present low organic matter production, where the countries of the South generally have a higher organic production, on average $67 \%$ of the total generated (WILSON et al., 2012).

Although rich countries are ahead, it is still a challenge to efficiently manage the solid waste generated by the world's population, with the main obstacles involved being: the lack of integration between public agencies and the informal sectors that participate in the segregation and sale of waste; Lack of concern about the reduction in generation; And low standardization in the collection (VERGARA \& TCHOBANOGLOUS, 2012).

Waste management techniques (e.g. biological treatment for the organic fraction), disposal (e.g. landfill or incineration for energy recovery) and the recovery of recyclable waste (with their recycling, reuse and reuse) are important in waste management (BARROS, 2012).

A survey by the International Solid Waste Association (ISWA) found that the world's seven billion people generate about 1.4 billion tonnes of urban solid waste, where parts of Africa, Southeast Asia and Latin America do not have no collection. On average, US $\$ 40$ billion would be needed to solve the problem related to collection alone, estimating also that by 2050, reaching 9 billion people, the volume of waste generated would be equal to 4 billion tons (ESTADÃO, 2013). According to the World Bank, annual costs for solid urban waste management, which in 2012 were approximately US \$205.4 billion, will increase to US \$ 375.5 billion in the year 2025 (ROSS \& ROGOFF, 2012).

In developing country India, the waste is deposited in dumps, which is a problematic issue and difficult to solve for the public managers there. In an investigation carried out by the Indian Central Pollution Control Board (JPAC), where the main problems were addressed in the country when it comes to waste management, the sum of waste generated in one year was 35,401 tons, it is divided by 59 cities (SRIVASTAVA et al., 2014). In general, the volume of waste resulting from the activities of the Indian population is around $0.50 \mathrm{~kg} / \mathrm{day}$, and this is recorded in 2011 (KALYANI \& PANDEY, 2014).

In China, another developing country, landfills, composting and incineration of waste are the most used in the treatment of waste, these technologies accounting for $78 \%$ of the total volume of waste. Although important for environmental quality, landfills and incineration are targeted as villains due to the gases emitted by these technologies. In addition, another problem is the lack of laws and a system that allows the monitoring of pollution (TIAN et al., 2013).

According to information for the year $2013,75 \%$ of the waste generated in Russia was still sent to landfills or dumps, and no recycling or reuse technologies were applied, with the average generation of waste in the country equal to 3.5 billion tons Every year (THE MOSCOW TIMES, 2013). South Africa, through its Law No. 59 of 2008, set goals to be achieved throughout the country to promote the proper management of its waste. As elsewhere, there is concern about the production of Cleaning Production, minimization, reuse and recycling. The policy points to final disposal as the last option for solid waste (SOUTH AFRICAN WASTE INFORMATION CENTER, 2016).

The European continent is one of the richest parts of the world, with good examples of solid waste management, such as Paris and Berlin. On average, every European citizen generates six tonnes of waste per year. Even with good environmental policies for solid waste, a significant amount of material is still lost, which can serve as a raw material for different production processes. Of the 
2.5 million tonnes of waste generated in 2010 , only $36 \%$ were recycled, a major criticism of the systems adopted, which are still flawed in consumption reduction policies, for example (EUROPEAN COMISSION, 2016).

In the year 2012 the total volume of waste generated in the European Union was 2,514 million tonnes of waste, which is higher than in 2008 and 2010 (2,460 million tonnes and 2,427 million tonnes respectively). Compared with 2012, this figure was lower (2,565 million tonnes) in 2004, where one of the reasons for this is the problems faced by the economy (Eurostat, 2016). Spain, for example, has a differentiated system of solid waste collection, which is sent to the underground sorting centre, and in Germany, like other European cities, citizens are monetarily subsidized for each PET bottle returned to the company that Produced the material (Figures 1 and 2).

A

B

$\mathrm{C}$

$\mathrm{D}$

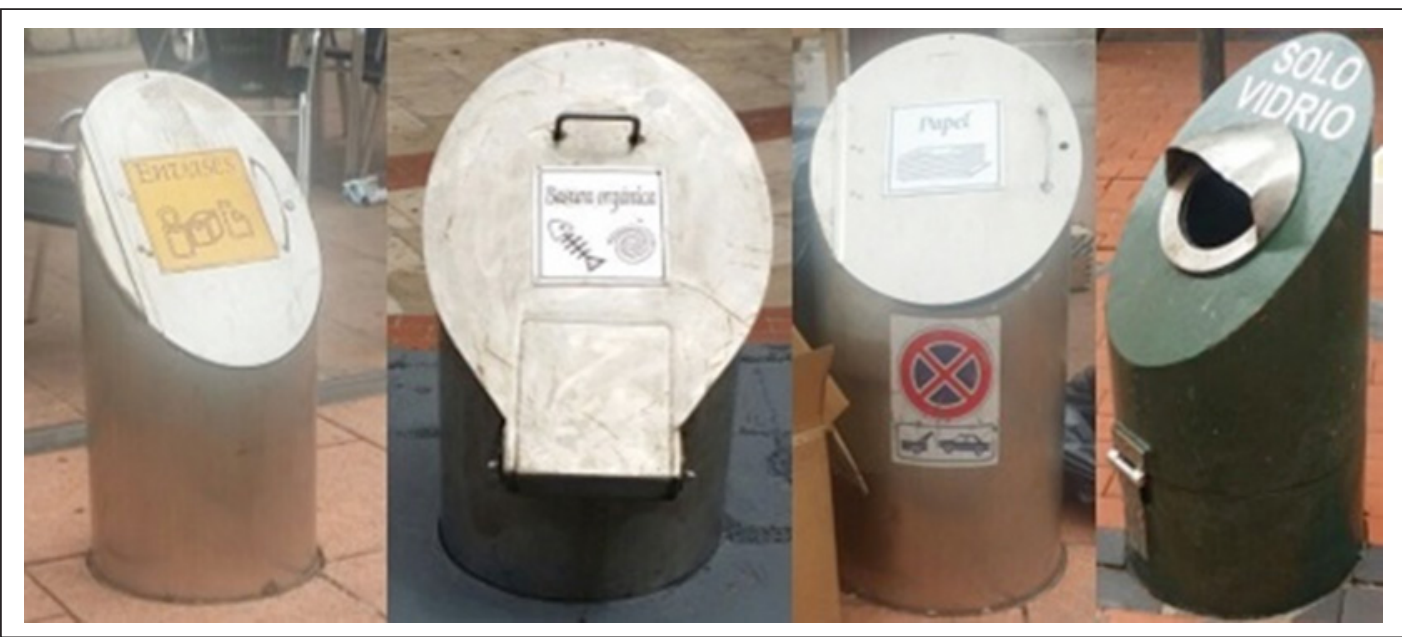

Figure 1 - Selective collection in Valencia, Spain, where the waste is sent to the plant through an underground system. A) Packaging. B) Organic matter. C) Paper. D) Glass.

Source: Author (2017).

A

B

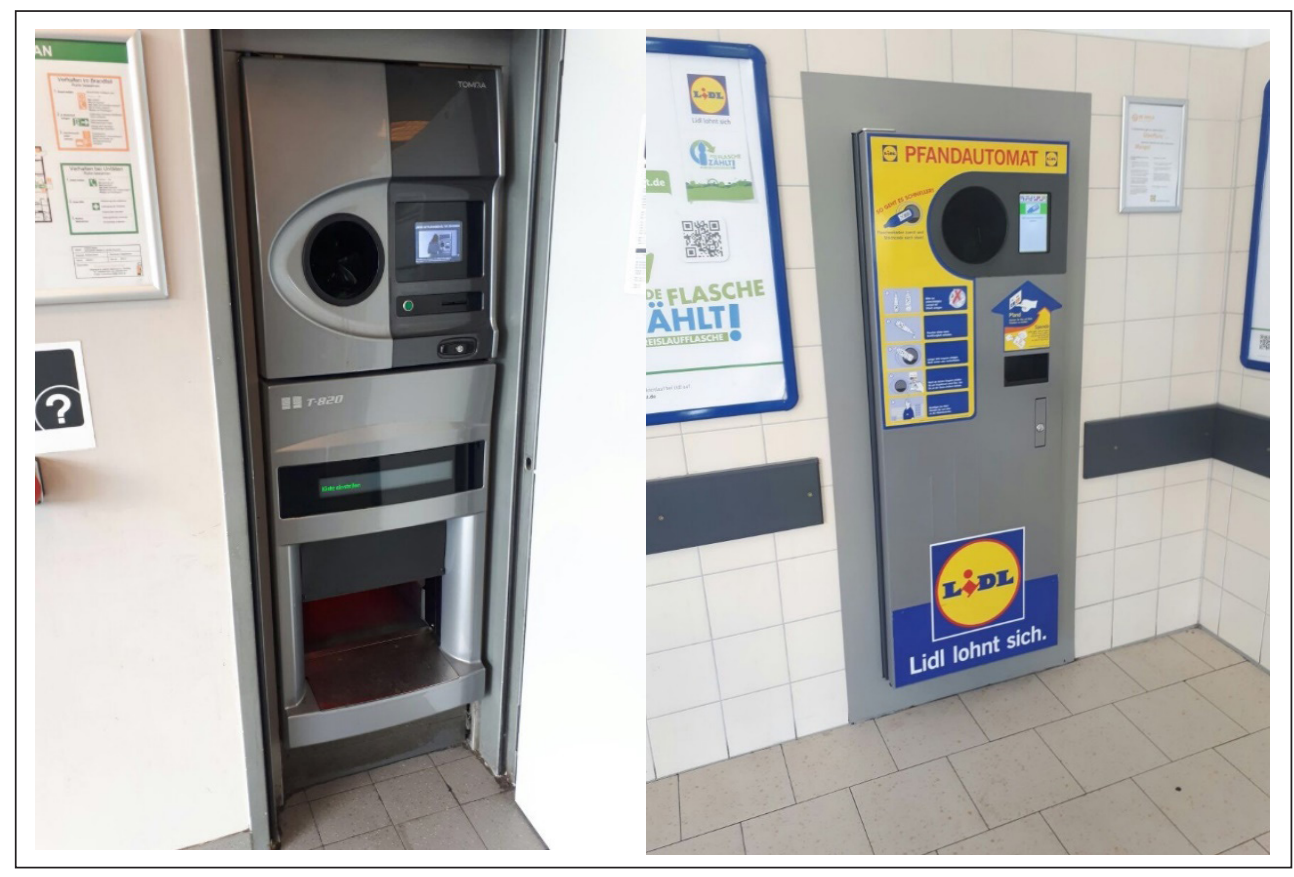

Figure 2 - PET bottle collecting machine in Chemnitz (A) and Leipzig (B), Germany.

Source: Author (2017). 
In its 98th year directive 2008, the European Union sets out the basic definitions and concepts related to waste management, defining what waste is, what is recycling and what is recovery. Other important aspects are the definition of when waste ceases to be waste and becomes secondary raw material (so-called end-of-waste criteria) and how to distinguish between waste and by-products.

This Directive also establishes some basic principles of waste management, e.g. by requiring waste to be managed without posing a risk to human health or to the environment and without risks to water, air, soil, plants or animals, without causing annoyance by noise or odours and without adversely affecting the rural environment or places of special interest. The Member States of the European Union are subject to these, and there is a hierarchy of priorities: prevention not to generate, reuse, recycle, recover and then final disposal (EUROPEAN COMISSION, 2016).

Another important instrument for waste management in the European Union is Directive 75/442, which sets out the basic requirements for waste treatment, and defines what they are. With respect to hazardous waste, Directive 91/689 brings the definition of hazardous waste and defines criteria for its management. The PCB / PCT Directive (Directive 96/59 relates to the disposal of polychlorinated biphenyls and polychlorinated terphenyls), addressing the leachate of these chemicals which pose risks to the environment and to human health.

About waste oils, Directive $75 / 439$, as amended by Directive $87 / 101$, aims to create a harmonized system for the collection, treatment, storage and disposal of waste oils, such as vehicle lubricating oils. The use of sewage sludge in agriculture is controlled by Directive $86 / 278$. On landfills, the rules for final disposal are laid down by Directive 1999/31, providing for the need for a plan. Operational and technical requirements, with the definition of limit values for waste incineration plants, are laid down in Directive 2000/76 of 4 December 2006. Directive 94/62 deals with packaging waste. On the life cycle of vehicles, Directive 2000/53 defines measures for the reuse of waste from motor vehicles and vehicle components. Finally, Directive 2002/96, as amended by Directive 2003/108, aims to prevent the production of electrical and electronic waste and to promote reuse, recycling and other forms of recovery to reduce the quantity of such waste to be disposed of by disposal in landfill or incineration (CITIZENS INFORMATION, 2011).

\section{WASTE MANAGEMENT IN BRAZIL AND BELO HORIZONTE}

In Belo Horizonte, the beginning of ideas related to waste started in 1894, and the municipality is a national highlight in waste management. According to the National Policy on Solid Waste, 2012 was the deadline for the federation, states and municipalities to finalize their PGIRS (BRAZIL, 2010). On December 14, 2015, the first public hearing was held, where the company MYR presented the diagnosis made to the members of the West region, Barreiro and South-Central. In addition to representatives of the company hired by the Secretary of Urban Cleaning (SLU), there were also pickers and some civilians. At the time, they were the Director of the Thematic Discussion Group and the Coordinator of the Technical Group of Contract Supervision. The hiring of the company was by way of price-taking.

At the national and international level, some of the factors that discard the possibilities of depositing residues near residences are the impacts on human health, the need for environmental protection and the reduction in the availability of large areas for solid waste disposal (YADAV et al. 2017). In 1975, the Sanitary Landfill and the Sorting and Composting Plant were installed, making it possible to recycle some of the recyclable waste and organic matter.

In 2010, Brazil took a major step towards a regulatory framework related to the management and management of solid waste. Aiming at the, which is the sustainable development and greater control of pollution caused by the inconsequent disposal of garbage in the environment, the creation and regulation of the National Solid Waste Policy (PNRS) was developed.

Scremin et al state (2014, p. 204) that, because of the approval of Law No. 12,305 / 10, which establishes the PNRS, the National Solid Waste Plan is in the process of being built, which will cover the various types of waste generated and as the first item of the minimum content the diagnosis of the current solid waste situation. In October 2014, the city of Belo Horizonte announced the beginning of the preparation of the Municipal Integrated Solid Waste Management Plan (PMGIRS). This was 
developed based on the diagnosis, identification of possibilities for associated management, planning of actions, presentation and dissemination of the final version of the PMGIRS, and the final version was made in March 2017. 4), advisory boar and executive secretariat.

The body responsible for solid waste management is the Urban Cleaning Secretariat (SLU). The SLU is responsible for the elaboration, control and execution of programs and activities aimed at urban cleaning of the city. Created in 1973, SLU provides household waste collection, sweeping, weeding, waste landfilling, selective waste collection, recycling of waste and composting (PBH, 2016).

The collection of urban waste is done in $96 \%$ of the formal urbanization areas and in $76 \%$ of the low-income housing, shantytowns and housing complexes that receive collection trucks from the prefecture, where $95 \%$ of the population is served with the collection. Some neighborhoods service at night. There is also special and differentiated collection and collection of dead animals (PBH, 2016). Based on Table 1, the situation of the municipality with respect to its municipal solid waste can be visualized.

Chart 1 - Information about the solid waste in Belo Horizonte

\begin{tabular}{c|c}
\hline \multicolumn{2}{c}{ WASTE COLLECTION IN BELO HORIZONTE } \\
\hline Dailly collection & $\begin{array}{c}2.2 \text { thousand tons of household waste. } \\
300 \text { tons of clandestine depositions. } \\
18 \text { tons of recyclables. }\end{array}$ \\
\hline Clean sacks & 1.900 km. \\
\hline Number of bins & 25,500 unities. \\
\hline Compliance with gutters & 30 km. \\
\hline Selective collection & 384,000 inhabitants. \\
& 123,000 households. \\
\hline WASTE COLLECTION IN BELO HORIZONTE (CONTINUATION) & 266 containers. \\
\hline Selective peer-to-peer collection & 19,000 unities monthly. \\
\hline Tires collected & 18 tonnes monthly. \\
\hline Animal collecteds & 90,000 toneladas per year. \\
\hline Recycling of building rubble & 211,000 m2 monthly. \\
\hline Cleaning of streams & 460,000 actions of cleaning every year. \\
\hline Sewer cleaning & $\begin{array}{c}\mathrm{h} \text { to11h; from } 11 \mathrm{~h} 40 \text { to } 15 \mathrm{~h} \text {; from } 15 \mathrm{~h} \text { to } 19 \mathrm{~h} ; \\
\text { from } 19 \mathrm{~h} \text { to } 24 \mathrm{~h} \text {; from } 23 \mathrm{~h} \text { to } 6 \mathrm{~h} .\end{array}$ \\
\hline Time of sweeping & $\begin{array}{c}\text { Five workers ten times monthly, concentrated } \\
\text { in the central region. }\end{array}$ \\
\hline Graffiti cleaning & $\begin{array}{c}\text { From Sunday to Sunday in the evening round } \\
\text { Praça Sete. }\end{array}$ \\
\hline Washing & Monthly withdrawal of advertising papers. \\
\hline Multitasking &
\end{tabular}

Source: Author (2017)

In 1972 the city of Belo Horizonte elaborated its Metropolitan Plan of Urban Cleaning, and before that period the city deposited its garbage in the open area (SILVA, 2002). Assessing the implications related to solid waste management, one must estimate the recurrent economic and environmental impacts of waste management, related to the segregation, treatment and disposal of what is collected, besides the need to estimate what can be obtained with energy recovery, for example (MARTINEZ-SANCHEZ et al., 2017).

In a study involving 39 municipalities where the objective was to analyse the impacts of the PNRS in the selective collection (one of the points addressed in Law 12,305) of the metropolitan region of São Paulo, it was verified that although the selective collection, especially that practiced by 
organizations of collectors, had an increase in the period between 2004 and 2013, there were no significant advances in the period from 2010 to 2013, after the approval of the PNRS (BESEN et al., 2014).

In the Brazilian policy for solid waste management, several instruments are used. Law 12,305 of August 2, 2010 is considered the most important. Through this legal instrument was established the concept of reverse logistics of waste, deadlines for the realization of municipal waste management plans and shared responsibility for the product life cycle, for example.

Another instrument is CONAMA Resolution No. 275, of April 25, 2001. This establishes the colour code for the different types of waste, to be adopted in the identification of collectors and transporters, as well as information campaigns for selective collection. Its application is of extreme importance in commercial establishments and for municipal selective collection programs. It can be said that operational and cost problems, as well as the lack of information, lead to its inadequate disposal, causing environmental changes, as well as risks to public health, resulting in negative impacts, objectionable from a sanitary and environmental point of view (GONÇALVES, 2011).

Health service residues (RSS) are in the special group, with $52 \%$ of those with infectious potential coming from patients undergoing short rehabilitation, followed by laboratories $(23 \%)$, surgeries $(14 \%)$, dialysis (7\%) and first aid (4\%), with the reduction and adequate destination, some important aspects to be followed (WINDFIELD \& BROOKS, 2015). In relation to solid waste of health care system, CONAMA's resolutions 358 of 2005 and RDC 306 of 2004 of the National Agency of Sanitary Surveillance (NASS) are also important. The first deals with the treatment and final disposal of waste from health services and provides other measures and the second deals with the technical regulation for the management of waste health services. In this area, ABNT 12808 of 1993 classifies health care waste as potential risks and ABNT 10.004 of 2004 classifies solid waste according to the hazard category.

CONAMA Resolution No. 307, of July 5, 2002, establishes guidelines, criteria and procedures for the management of construction waste. According to Angulo (2011, p. 300): "The publication of the CONAMA 307 resolution motivated some municipalities to implement waste management plans for civil construction."

\section{CONCLUSIONS}

Although having an important regulatory framework on solid waste management, this being Law 12,305 of August 2010, Brazil is behind schedule when it comes to the application of what is regulated. In the year 2015, it was decided to extend the deadline for the municipalities to close their dumps and then to implement their landfills, something that was not fulfilled. Thus, it was decided by the extension of the term, action that view by different scholars as an error.

During the present study, it was noticed that among the main laws in the Brazilian management model, compliance with deadlines established by law, different from the model adopted in Europe, is observed after the deadline, sanctions are applied on the generator of the waste that does not comply. Although made under interruptions, the waste management plan of Belo Horizonte was launched in 2017, being considered one of the most complete.

\section{REFERENCES}

ANGULO, S. C.; TEIXEIRA, C. E.; CASTRO, A. L.; NOGUEIRA, T. P. Resíduos de construção e demolição: avaliação de métodos de quantificação. Engenharia Sanitária e Ambiental, Rio de Janeiro, vol. 16, n. 3, p. 299-306, jul./set. 2011.

BARROS, R. T. V. Elementos de gestão de resíduos sólidos. Belo Horizonte: Tessitura, 2012. 424 p.

BESEN, G. R.; RIBEIRO, H.; GÜNTHER, W. M. R.; JACOBI, P. R. Coleta seletiva na Região Metropolitana de São Paulo: impactos da Política Nacional de Resíduos Sólidos. Ambiente \& Sociedade, vol. 17, n. 3, p. 259-278, jul./set. 2014. 
BRASIL. Lei $\mathrm{N}^{\circ} 12.305$, de 2 de agosto de 2010. Institui a Política Nacional de Resíduos Sólidos; altera a Lei no 9.605, de 12 de fevereiro de 1998; e dá outras providências. Disponível em: <http://www.planalto.gov.br/ ccivil_03/_ato2007-2010/2010/lei/112305.htm>. Acesso em: 19 set. 2015.

BRASIL. Senado Federal. Senadores aprovam prorrogação do prazo para fechamento dos lixões. Disponível em: <http://www12.senado.leg.br/noticias/materias/2015/07/01/senadores-aprovam-prorrogacao-do-prazo-para-fechamento-dos-lixoes>. Acesso em 30 out. 2015.

CITIZENS INFORMATIONS. Public Service Information. 2011. Provided by the Citizens Information Board. Disponível em: <http://www.citizensinformation.ie/en/environment/environmental_law/waste_ management.hhtm>. Acesso em: 29 jun. 2016.

COUTO, M. C. L.; BRAGA, F. S.; LANGE, L. C. Tratamento de lixiviado por infiltração rápida como alternativa para cidades de pequeno porte. Engenharia Sanitária e Ambiental, Rio de Janeiro, vol. 18, n. 3, p. 223-234, jul./set. 2013.

DÍAZ-VILLAVICENCIO, G.; DIDONET, S. M.; DODD, A. Influencing factors of eco-efficient urban waste management: Evidence from Spanish municipalities. Journal of Cleaner Production, USA, vol. 164, p. 14861496, 2017.

ESTADÃO. Sustentabilidade. Metade do mundo não coleta lixo e universalizar serviço custaria US\$40 bi. Disponível em: <http://sustentabilidade.estadao.com.br/noticias/geral,metade-do-mundo-nao-coleta-lixo-e-universalizar-servico-custaria-us-40-bi,1100766>. Acesso em: 04 jun. 2016.

EUROPEAN COMISSION. Environment. 2016. Disponível em: <http:// http://ec.europa.eu/environment/ waste/>. Acesso em: 29 jun. 2016.

EUROSTAT - ESTATISTICS EXPLAINED. Waste statistics. 2016. Disponível em: < http://ec.europa.eu/ eurostat/statistics-explained/index.php/Waste_statistics>. Acesso em: 29 jun. 2016.

FERREIRA, E. M.; CRUVINEL, K. A. S.; COSTA, E. S. Disposição final dos resíduos sólidos urbanos: diagnóstico da gestão do município de Santo Antônio de Goiás. Revista Monografias Ambientais, Santa Maria, vol. 14, n. 3, p. 3401-3411, mai-ago. 2014.

GONÇALVES, E. M. N; SANTOS, C. B; BADARÓ, M. L. S; FARIA, V. A; RODRIGUES, E; MENDES, M. E; SUMITA, N. M. Modelo de implantação de plano de gerenciamento de resíduos no laboratório clínico. Jornal Brasileiro de Patologia e Medicina Laboratorial, Rio de Janeiro, vol. 47, n. 3, p. 249-255, jun. 2011.

GONÇALVES, M. A.; VALE, M. M. A. A. V. Q.; GONÇALVES, A. H. Um estudo comparado entre a realidade brasileira e portuguesa sobre a gestão dos Resíduos Sólidos Urbanos. Sociedade \& Natureza, Uberlândia, vol. 28, n. 1, p. 9-20, jan./abr. 2016.

JABBOUR, A. B. L. S.; JABBOUR, C. J. C.; SARKIS, J.; GOVINDAN, K. Brazil's new nationalpolicyonsolidwaste: challengesandopportunities. Clean Technologies and Environmental Policy, USA, vol. 16, p. 7-9, Jan. 2014.

JARA-SAMANIEGO, J.; PÉREZ-MURCIA, M. D.; BUSTAMANTE, M. A.; PÉREZ-ESPINOSA, A.; PAREDES, C.; LÓPEZ, M.; LÓPEZ-LLUCH, D. B.; GAVILANES-TERÁN, I.; MORAL, R. Composting as sustainable strategy for municipal solid waste management in the Chimborazo Region, Ecuador: Suitability of the obtained composts for seedling production. Journal of Cleaner Production, USA, vol. 141, p. 1349-1358, Jan. 2017.

KALYANI, K. A \& PANDEY, K. K. Waste to energy status in India: A short review. Renewable and Sustainable Energy Reviews - Elsevier, USA, vol. 31, p. 113-120, Mar. 2014. 
MARSHALL, R. E \& FARAHBAKHSH, K. Systems approaches tointegratedsolidwaste management in developing countries. Waste Management-Elsevier, USA, vol. 33, p. 988-1003, Ap. 2013.

MARTINEZ-SANCHEZ, V.; LEVIS, J. W.; DAMGAARD, A.; DECAROLIS, J. F.; BARLAZ, M. A.; ASTRUP, T. F. Evaluation of Externality Costs in Life-Cycle Optimization of Municipal Solid Waste Management Systems. Environmental Science \& Technology, USA, vol. 51, p. 3119-3127, 2017.

ROSS, D. E \& ROGOFF, M. J. 'What a waste...' the World Bank's call for action. Waste Management \& Research, USA, vol. 30, p. 755-757, 2012.

SCREMIN, L. B.; CASTILHOS JUNIOR, A. B.; ROCHA, J. C. Sistema de apoio ao gerenciamento de resíduos de construção e demolição para municípios de pequeno porte. Engenharia Sanitária e Ambiental, Rio de Janeiro, vol. 19, n. 2, p. 203-206, abr./jun. 2014.

SILVA, H. Aspectos demográficos associados à geração de resíduos domiciliares no município de Belo. Horizonte. 2002. 203 f. Dissertação (Mestrado em Demografia) - Centro de Desenvolvimento e Planejamento Regional, Faculdade de Ciências Econômicas, Universidade Federal de Minas Gerais, Belo Horizonte. 2002.

SILVA, C. L.; FUGII, G. M.; SANTOYO, A. H. Proposta de um modelo de avaliação das ações do poder público municipal perante as políticas de gestão de resíduos sólidos urbanos no Brasil: um estudo aplicado ao município de Curitiba. urbe. Revista Brasileira de Gestão Urbana, Curitiba, vol. 9, n. 2, p. 276-292, mai./ago. 2017 Epub 23-Mar-2017.

SOUTH AFRICAN WASTE INFORMATION CENTRE. Approach to waste in South Africa. 2016. Disponível em: <http://sawic.environment.gov.za/?menu=60>. Acesso em: 04 jun. 2016.

SRIVASTAVA, V.; ISMAIL, S. A.; SINGH, P.; SINGH, R. P. Urban solid waste management in the developing world with emphasis on India: challenges and opportunities. Reviews in Environmental Science and Biotechnology, vol. 14, Issue. 2, p. 317-337, Oct. 2014.

SUPERINTENDÊNCIA DE LIMPEZA URBANA - BELO HORIZONTE. Plano Municipal de Gestão Integrada de Resíduos Sólidos de Belo Horizonte. 2017. Disponível em: <http://file:///C:/Users/Evaldo/ Downloads/apresentacao_evento-final.pdf>. Acesso em: 20 jul. 2017.

THE MOSCOW TIMES. B2B: Waste management in Russia. Disponível em: <http://www.themoscowtimes. com/article/479656.html>. Acesso em: 04 jun. 2016.

TIAN, H.; GAO, J.; HAO, J.; LU, L.; ZHU, C.; QIU, P. Atmospheric pollution problems and control proposals associated with solid waste management in China: A review. Journal of Hazardous Materials - Elsevier, USA, vol. 252-253, p. 142-154, May. 2013.

TRIGUERO, A.; ÁlVAREZ-ALEDO, C., CUERVA, M. C. Factors influencing willingness to accept different waste management policies: empirical evidence from the European Union. Journal of Cleaner Production Elsevier, USA, p. 1-9, Jun. 2016.

VERGARA, S. E \& TCHOBANOGLOUS, G. Municipal Solid Waste and the Environment: A Global Perspective. Annual Review of Environment and Resources, USA, vol. 37, p. 277-309, 2012.

WILSON, D. C.; RODIC, L.; SCHEINBERG, A.; VELIS, C. A.; ALABASTER, G. Comparative analysis of solid waste management in 20 cities. Waste Management \& Research, vol. 30, p. 237-254, 2012.

WINDFIELD, E. S \& BROOKS, M. S-L. Medical waste management - A review. Journal of Environmental Management, USA, vol. 163, p. 98-108, Nov. 2015. 
YADAV, V.; BHURJEE, A. K.; KARMAKAR, S.; DIKSHIT, A. K. A facility location model for municipal solid waste management system under uncertain environment. Science of The Total Environment, USA, vol. 603-604, p. 760-771, 2017. 